\title{
DESIGN AND FABRICATION OF PEDAL POWERED WASHING MACHINE
}

Prof. G. S. Jagushte ${ }^{1 *}$, Akashdeep Singh ${ }^{2}$, Gourang Bhatawdekar ${ }^{3}$, Salman Budye ${ }^{4}$, Nilesh Chiplunkar ${ }^{5}$

${ }^{*}$ Assistant Professor in Mechanical Engineering Department of Rajendra Mane college of Engineering and Technology, Ambav (Ratnagiri) Mumbai University, India

2, 3, 4\&5 Student in Mechanical Engineering Department of Rajendra Mane college of Engineering and Technology, Ambav (Ratnagiri) Mumbai University, India

*1jagushteganesh99@gmail.com, 2akashdeepsingh540@gmail.com, ${ }^{5}$ chiplunkar.nilesh@gmail.com

*Corresponding Author: -

jagushteganesh99@gmail.com

\begin{abstract}
: -
The Pedal Operated Washing Machine is the project which is best option for rural area where there is a problem of electric supply or there is shortage of electric supply. To run the washing machine there is a need of electric power and most of villages of India are suffering from this problem and so overcome and to solve this problem we selected washing machine which operated manually. This does not require any electric power supply or diesel supply. This project is low weight and portable so that easily transported. We use the simple cycling mechanism to run the machine shaft.
\end{abstract}

Keywords: -"Pedal Power, Washing machine, Electric power, Fabrication, Machine shaft, shortage of electricity"

\section{(c) $(\$)$}




\section{INTRODUCTION}

A washing machine, clothes washer, or simply washer, is a machine designed to wash laundry, such as clothing, towels and sheets. The term is mostly applied only to machines that use water as the cleaning solution, as opposed to dry cleaning (which uses alternative cleaning fluids, and is performed by specialist businesses) or even ultrasonic cleaners. All washer machines work by using mechanical energy, thermal energy, and chemical action. Mechanical energy is imparted to the clothes load by the rotation of the agitator in top loaders, or by the tumbling action of the drum in front loaders. Thermal energy is supplied by the temperature of the wash bath. The spin speed in these machines can vary from 500 to $1600 \mathrm{rpm}$.

The machine -PADDEL OPERATED WASHING MACHINE $\|$ is innovative to manufacture and it requires skill to manufacture. The parts can be manufacture in our college. Its subcomponent price is also less, but its manufacturing requires sort of skill. This project gives us knowledge, experience skill and new ideas of manufacturing. It is a working project and having guarantee of success. This project can be made in less time; hence we have selected this project.

\section{Principle}

The machine entitled - PADDEL OPERATED WASHING MACHINE\| Works on the principle of rotating impeller by paddling and causes to washing clothes. The basic idea is to use a stationary bicycle stand as the power source, and use an assembly of chain drive to connect it to an old, salvaged washing machine tub.

\section{A. Operating Procedure}

In paddle rotates the rotor of washing machine. A two set of chain is fixed on washing machine shaft is rotated by means of peddling. The paddle sprocket is attached with heavy flywheel which store energy and transmit it when required. There are several benefits to this system, in addition to the electricity savings. The grey water from this washing can be recycled for filling toilet tanks or for watering plants. It puts moisture into the air, which is especially good in the wintertime. It also provides an aerobic workout for the rider, which also puts heat (and some additional moisture) into the air, which is also a good thing in the wintertime.

\section{B. Project Setup}

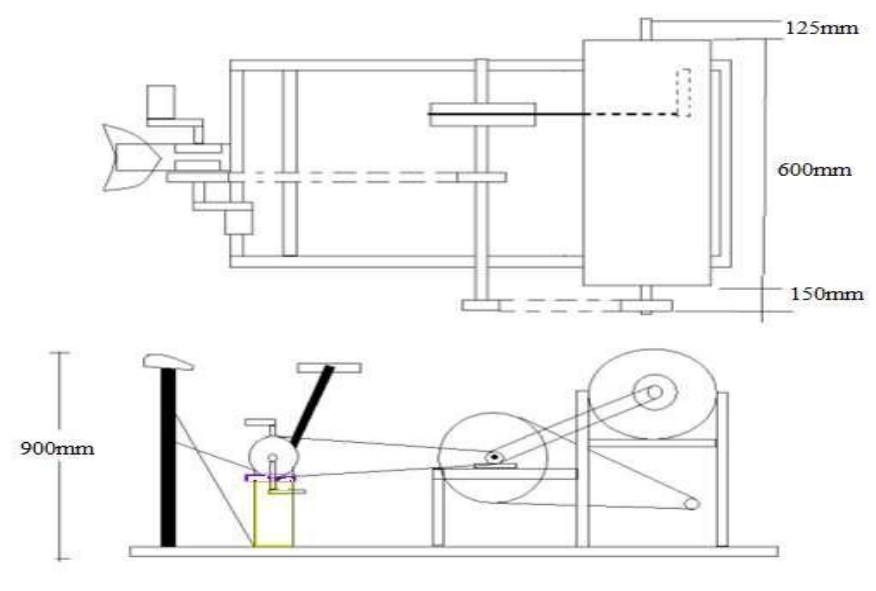

Fig. 1 Detail information of each component of the machine.

\section{General Assumption in Design of Machine}

[1] Output rpm of washing machine is $800 \mathrm{rpm}$

[2] Load of person sitting on a machine $=100 \mathrm{~kg}=100 * 9.81=9810 \mathrm{~N}=1000 \mathrm{~N}$

[3] Normal paddling RPM = $100 \mathrm{rpm}$

[4] Force Applied at Paddling $=50 \mathrm{~kg}=50 * 9.81=49.05 \mathrm{~N}=50 \mathrm{~N}$

As we know a normal person can apply $100 \mathrm{rpm}$ in normal working condition. As per this assumption we design transmission of system

$$
\begin{aligned}
\frac{N_{\text {Big sprocket }}}{N_{\text {Small sprocket }}} & =\frac{D_{\text {small sprocket }}}{D_{\text {big sprocket }}} \\
\frac{100}{x} & =\frac{80}{170}
\end{aligned}
$$




$$
\begin{gathered}
x=\frac{100 * 170}{80} \\
x=212 \mathrm{rpm} \\
N_{\text {small Spocket }}=212 \mathrm{rpm}
\end{gathered}
$$

The flywheel is rigidly fixed with small sprocket shaft flywheel increase rpm of wash drum so resultant rpm of wash drum is magnify. The resultant rpm of washing mc is $800 \mathrm{rpm}$

$$
N_{\text {washing machine }}=800 \mathrm{rpm}
$$

As design washing machine rpm is sufficient to run the machine.

\section{Rpm of dynamo}

$$
\begin{gathered}
\frac{N_{\text {flywheel }}}{N_{\text {dynamo }}}=\frac{D_{\text {dynamo }}}{D_{\text {flywheel }}} \\
\frac{212}{x}=\frac{20}{410} \\
x=\frac{210 * 410}{20} \\
x=4346 \mathrm{rpm} \\
N_{\text {Speed of the dynamo }=4346 \mathrm{rpm}}
\end{gathered}
$$

\begin{tabular}{|c|c|c|c|c|}
\hline Sr.no. & $\begin{array}{l}\text { Name of The } \\
\text { Component }\end{array}$ & Specification & Material & Quantity \\
\hline 1 & Angle frame & $40 \times 40 \times 4$ & MS & 01 \\
\hline 2 & Chain & $1 / 2$ inch Pitch & Carbon Steel & 2 \\
\hline 3 & Sprockets & $1 / 2$ inch Pitch & MS & 4 nos \\
\hline 4 & Shaft & $20 \mathrm{~mm}$ dia & M.S. & 4 nos \\
\hline 5 & Bearings & p 204 & $\mathrm{CI}$ & 8 \\
\hline 5 & Wash tub & $\begin{array}{l}300 \times 350 \times 700 \\
\mathrm{~mm}\end{array}$ & MS & 1 \\
\hline 6 & Flywheel & $350 \mathrm{~mm}$ dia & MS & 1 \\
\hline 7 & Handle & & MS & 1 \\
\hline 8 & Paddle & & & 1 \\
\hline 9 & Gear & 260 dia & MS & 2 \\
\hline 10 & Gear box & $1: 1$ & $\mathrm{AL}$ & 1 \\
\hline 11 & Lob & 8 inch dia & PVC & 2 \\
\hline 12 & Seat & & & 1 \\
\hline
\end{tabular}

As design washing machine rpm, dynamo rpm is sufficient to run the machine and power generation.

\section{Selected Materials}

\section{Table I Material Specification}

\section{Conclusion}

The machine must be inexpensive and easily build so that the community will accept it. We consider the need of the people living in the rural area and consider the shortage of electric supply we made this project start with low cost mind set. The components uses in this project are easily available in rural area. The machine uses the bicycle parts which are available everywhere. Pedal powered washing machine is different from people washing their clothes in rural areas. We achieved what we desired i.e. to build the manually driven pedal powered washing machine using the easily available component and material. The main advantage of washing machine is that it does not consume the electricity. By using this people can wash clothes during their workout and exercise. If the production of this washing machine is done at the commercial scale then the total production cost of the machine will reduced to $40 \%$ of the estimated cost and there will saving in the electric power supply. 


\section{References}

[1] S.M.Moghe and K.S.Zakiuddin, Design and Development of Turmeric Polishing Machine Energized by Human Power Flywheel Motor, A past review proceedings of the 1st International and 16th National Conference on Machines and Mechanisms, IIT Roorkee, India, Dec.18, 2013.

[2] Bruzzon M and Wieler.A. (2010),"Reflecting on a Intercultural Design-Build Project", in the Kathmandu Valley Final Draft, February 5, 2015.

[3] "Bicilavodra", The Pedal Powered Washing Machine, IDEA-2005 Proposal. 